\title{
ANTIVENOM REVERSAL OF BIOCHEMICAL ALTERATIONS INDUCED BY BLACK SCORPION Heterometrus fastigiousus COUZIJN VENOM IN MICE
}

\section{Chaubey MK (1)}

\section{(1) Department of Zoology, Mahatma Gandhi College, Gorakhpur, Uttar} Pradesh, India.

\begin{abstract}
In the present study, Heterometrus fastigiousus venom (HFV) was employed as antigen to produce species-specific scorpion antivenom (SAV) in albino mice (NIH) strain. To determine SAV efficacy, it was pre-incubated with $10 \mathrm{LD}_{50}$ of HFV and then injected subcutaneously into mice. Subsequently, mortality was observed after 24 hours. Minimum effective dose (MED) was $12.5 \mathrm{LD}_{50}$ of HFV/mL of SAV. SAV effectiveness to reverse HFV-induced biochemical alterations in mice was analyzed by challenge method. Simultaneously, mice received subcutaneously $40 \%$ of 24-hour-LD ${ }_{50}$ of HFV and intravenously SAV. After four hours, changes in serum glucose, free amino acids, uric acids, pyruvic acid, cholesterol, total protein, alkaline phosphatase, acid phosphatase, lactic dehydrogenase and glutamate-pyruvate transaminase enzyme level were determined. Treatment with species-specific SAV resulted in the reversal of HFV-induced biochemical alterations.
\end{abstract}

KEY WORDS: venom, antivenom, envenomation, Heterometrus fastigiousus, serotherapy.

CONFLICTS OF INTEREST: There is no conflict.

\section{CORRESPONDENCE TO:}

MUKESH KUMAR CHAUBEY, Post Graduate Department of Zoology, Mahatma Gandhi College, Gorakhpur, 273 001, UP, India. Phone: +91 09839427296. Email: chaubey.mukesh@rediffmail.com. 


\section{INTRODUCTION}

Scorpion stings cause several clinical manifestations in the victim and are common in tropical and subtropical countries (1). There are several drugs that are employed in the treatment of scorpion envenomations; however, the relief of venom induced hypertension, these substances may cause side effects. Therefore, scientists have turned their attention towards serotherapy as a safer treatment for scorpion stings. Nevertheless, there are contradictory opinions about the effectiveness of the scorpion antivenoms either in experimental animals or in scorpion sting victims. Some researchers consider antivenom the only specific treatment against scorpion stings, while others have questioned its usefulness in eliminating scorpion sting complications (2-5). However, for quick neutralization of scorpion venom toxic effects, serotherapy is a well-tested pharmaceutical method safely used in patients around the globe (6-8).

In India, the efficacy of species-specific antivenoms in neutralizing lethal factors of red scorpion venom has been tested by different scientific groups $(9,10)$. Despite the several attempts to investigate the consequences of scorpionism and to produce species-specific antivenom against scorpion venom, Asian black scorpions have attracted little attention. Still, several clinical manifestations of black scorpion stings have been reported (11-14). Chaubey (11) reported reduction in erythrocyte and increase in total leucocyte counts, blood hemoglobin, mean corpuscular hemoglobin, packed cell volume and plasma hemoglobin in mice envenomated by Heterometrus fastigiousus venom (HFV). Chaubey and Upadhyay (12) observed that HFV increases levels of glucose, free amino acids, uric acid, pyruvic acid and total protein while decreases cholesterol level in sera of experimentally envenomated albino mice. The same treatment also augmented enzyme activity levels of alkaline phosphatase, acid phosphatase, lactic dehydrogenase and glutamate-pyruvate transaminase in albino mice sera. The present study was carried out to determine the efficacy of species-specific SAV produced against HFV -induced abnormalities in albino mice.

\section{MATERIALS AND METHODS}

\section{Venom}

Living black scorpions $H$. fastigiousus were purchased from the animal supplying agency Zoological Animal UP, India. Venom was obtained by electric stimulation of 
scorpion telson. Both toxicity and $\mathrm{LD}_{50}$ of HFV has already been determined in albino mice by Chaubey and Upadhyay (12).

\section{Production of SAV}

Species-specific SAV against HFV was produced in albino mice (NIH strain, $25 \pm 5 \mathrm{~g}$ ) using Freund's complete and incomplete adjuvants (respectively, FCA and FICA). Immunogen for primary immunization was prepared by emulsifying equal volumes of venom and FCA, while boosting immunogen was prepared by emulsifying equal volumes of venom and FICA. Primary immunization was performed by injecting intramuscularly $100 \mu \mathrm{L}$ of immunogen containing $100 \mu \mathrm{g} \mathrm{HFV}$. The interval between the first two doses was two weeks and then boosting was done regularly in oneweek intervals with gradually increasing HFV doses. During this period animals were bled randomly to check detectable amount of antibodies by Ouchterlony method (15). After four months, mice were killed and collected plasma was processed using ammonium sulphate precipitation and pepsin treatment according to Kankonkar et al. (9)

\section{Neutralizing Ability of Species-specific SAV}

The neutralizing ability of the species-specific SAV was tested in albino mice $(25 \pm 5$ g) that were injected subcutaneously with 10 LD $_{50}$ of HFV (in $100 \mu \mathrm{L}$ solution) preincubated with $100 \mu \mathrm{L}, 200 \mu \mathrm{L}, 400 \mu \mathrm{L}, 800 \mu \mathrm{L}$ and $1000 \mu \mathrm{L}$ of SAV for two hours at $37^{\circ} \mathrm{C}$. Each pre-incubated mixture was subsequently adjusted with physiological buffer saline (PBS) to a final volume of $2 \mathrm{~mL}$. The injection volume was kept constant to $400 \mu \mathrm{L} /$ mouse. Control group received PBS only. Animal mortality was registered 24 hours after treatment.

\section{Efficacy Determination of Species-specific SAV in the Reversal of HFV-induced}

\section{Biochemical Abnormalities}

Experimental albino mice were divided into the following three groups:

- $\quad$ Group A: received physiological buffer only (Control group);

- Group B: received $40 \%$ of $24-$ hour-LD 50 of HFV $(150 \mu \mathrm{g})$;

- Group C: received $40 \%$ of $24-$ hour-LD 50 of $\operatorname{HFV~}(150 \mu g)+$ simultaneous intravenously administration of SAV. 
After four hours of treatment, serum levels of glucose, uric acid, pyruvic acid, free amino acids, total protein and cholesterol levels were calculated according to the method of Mendel et al. (16), Folin (17), Friedeman and Haugen (18), Spies (19), Lowry et al. (20) and Abell et al. (21). Additionally, serum levels of alkaline phosphatase (ALP), acid phosphatase (ACP), lactic dehydrogenase (LDH) and glutamate-pyruvate transaminase (GPT) enzyme activities were determined by Bergmayer (22), Annon (23) and Reitman and Frankel (24) methods respectively.

\section{Statistical Analysis}

Results were expressed as mean \pm SE of six replicates and were analyzed using Student's t-test to detect significant changes with controls and between treated groups (25).

\section{RESULTS}

To determine antivenom efficacy, mice were injected subcutaneously with $10 L_{50}$ of HFV pre-incubated with species-specific SAV $(100 \mu \mathrm{L}, 200 \mu \mathrm{L}, 400 \mu \mathrm{L}, 800 \mu \mathrm{L}$ and $1000 \mu \mathrm{L})$. After 24 hours, animal survival was recorded and found to rise with increased amount of SAV (Table 1). Species-specific SAV neutralizes 12.5 LD $_{50}$ of $\mathrm{HFV} / \mathrm{mL}$.

In another experiment, the efficacy of species-specific SAV to revert augmented levels of serum glucose, free amino acids, pyruvic acid, uric acid as well as to diminish cholesterol and to improve levels of alkaline phosphatase, acid phosphatase, lactic dehydrogenase and glutamate-pyruvate transaminase enzyme activity was determined by challenge method.

SAV significantly reversed biochemical changes induced by HFV (Tables 2 and 3). Glucose, free amino acid, uric acid, pyruvic acid and total protein levels in group B mice were $140.48 \%, 138.39 \%, 127.27 \%, 144 \%$ and $122.09 \%$ of the control group; and decreased to $106.04 \%, 104.89 \%, 107.27 \%, 108 \%$ and $104.53 \%$ in animals of group C after treatment with SAV (Table 2). Cholesterol level in group B was $71.48 \%$ of the control group; and increased to $96.41 \%$ in group $\mathrm{C}$ mice (Table 2). Activities of ALP, ACP, LDH and GPT in mice of group B were $135.64 \%, 120.78 \%, 131.37 \%$ and $156.16 \%$ of control group; and after treatment with SAV the values diminished to $103.96 \%, 101.30 \%, 104.29 \%$ and $105.60 \%$ in group C (Table 3 ). 
Table 1. Determination of neutralizing capacity of scorpion antivenom (SAV) against $H$. fastigiousus venom (HFV) in albino mice (NIH strain)

\begin{tabular}{c|c|c}
\hline $\begin{array}{c}\text { Amount of HFV } \\
(\boldsymbol{\mu g})\end{array}$ & $\begin{array}{c}\text { Amount of SAV } \\
(\boldsymbol{\mu L})\end{array}$ & $\begin{array}{c}\text { Number of living mice I } \\
\text { Number of total mice }\end{array}$ \\
\hline 1,500 & 0 & $0 / 10$ \\
\hline 1,500 & 100 & $1 / 10$ \\
\hline 1,500 & 200 & $3 / 10$ \\
\hline 1,500 & 400 & $10 / 10$ \\
\hline 1,500 & $800^{*}$ & $10 / 10$ \\
\hline 1,500 & 1,000 & \\
\hline
\end{tabular}

${ }^{*}$ Minimum effective dose (MED).

Table 2. SAV effect on the reversal of HFV-induced alterations in serum levels of glucose, free amino acids, uric acids, pyruvic acid, cholesterol and total protein in albino mice (NIH strain)

\begin{tabular}{|c|c|c|c|}
\hline Parameters & Group A & Group B & Group C \\
\hline Glucose $^{1}$ & $\begin{array}{c}64.15 \pm 0.89 \\
(100)\end{array}$ & $\begin{array}{c}90.12^{*} \pm 0.93 \\
(140.48)\end{array}$ & $\begin{array}{c}70.03 \pm 1.35 \\
(106.04)\end{array}$ \\
\hline Free amino acids ${ }^{1}$ & $\begin{array}{c}6.33 \pm 0.09 \\
(100)\end{array}$ & $\begin{array}{c}8.76^{*} \pm 0.08 \\
(138.39)\end{array}$ & $\begin{array}{c}6.64 \pm 0.14 \\
(104.89)\end{array}$ \\
\hline Uric acid $^{1}$ & $\begin{array}{c}2.20 \pm 0.04 \\
(100)\end{array}$ & $\begin{array}{c}2.80^{*} \pm 0.07 \\
(127.27)\end{array}$ & $\begin{array}{c}2.36 \pm 0.08 \\
(107.27)\end{array}$ \\
\hline Pyruvic acid ${ }^{1}$ & $\begin{array}{c}0.25 \pm 0.002 \\
(100)\end{array}$ & $\begin{array}{c}0.36^{*} \pm 0.002 \\
(144.00)\end{array}$ & $\begin{array}{c}0.29 \pm 0.006 \\
(108)\end{array}$ \\
\hline Cholesterol $^{1}$ & $\begin{array}{c}167.00 \pm 2.20 \\
(100)\end{array}$ & $\begin{array}{c}119.38^{*} \pm 1.53 \\
(71.48)\end{array}$ & $\begin{array}{c}178.00 \pm 2.89 \\
(96.41)\end{array}$ \\
\hline Total protein ${ }^{2}$ & $\begin{array}{c}3.53 \pm 0.04 \\
(100)\end{array}$ & $\begin{array}{c}4.31^{*} \pm 0.07 \\
(122.09)\end{array}$ & $\begin{array}{c}3.69 \pm 0.09 \\
(104.53)\end{array}$ \\
\hline
\end{tabular}

${ }^{1}$ Values represent $\mathrm{mg} / 100 \mathrm{~mL}$ serum; ${ }^{2}$ values represent $\mathrm{g} / 100 \mathrm{~mL}$ serum. Values in parentheses indicate the percent of change with respect to the control group, considered as $100 \%$.

${ }^{*}$ Significance: $p<0.05$ (Student's t-test). 
Table 3. SAV effect on the reversal of HFV-induced alterations in serum levels of alkaline phosphatase, acid phosphatase, lactic dehydrogenase and glutamatepyruvate transaminase enzyme activity in albino mice (NIH strain)

\begin{tabular}{c|c|c|c}
\hline Parameters & Group A & Group B & Group C \\
\hline \multirow{2}{*}{ ALP } & $1.01 \pm 0.03$ & $1.37^{*} \pm 0.04$ & $1.05 \pm 0.07$ \\
& $(100)$ & $(135.64)$ & $(103.96)$ \\
\hline \multirow{2}{*}{ ACP } & $0.688 \pm 0.008$ & $0.831^{*} \pm 0.008$ & $0.697 \pm 0.010$ \\
& $(100)$ & $(120.78)$ & $(101.30)$ \\
\hline \multirow{2}{*}{ LDH } & $103.87 \pm 1.16$ & $136.46^{*} \pm 1.66$ & $108.33 \pm 1.16$ \\
& $(100)$ & $(131.37)$ & $(104.29)$ \\
\hline \multirow{2}{*}{ GPT } & $15.17 \pm 0.52$ & $23.69^{*} \pm 0.51$ & $16.02 \pm 0.52$ \\
& $(100)$ & $(156.16)$ & $(105.60)$ \\
\hline
\end{tabular}

ALP and ACP: $\mu$ moles of p-nitrophenol formed per 30 minutes per mg protein. LDH: $\mu$ moles of pyruvate reduced per 45 minutes per mg protein. GPT: units of glutamate-pyruvate transaminase activity per hour per mg protein. Values in parentheses indicate the percent of change in enzymatic activity compared to the control group, considered as $100 \%$.

*Significance: $p<0.05$ (Student's t-test).

\section{DISCUSSION}

Lethality due to scorpion stings is a common health problem in developing countries.

Of the 1,500 scorpion species distributed throughout the world, 50 have proven lethal to humans and most of them belong to Buthidae family (26). However, some species within the family Scorpionidae have also been reported as poisonous including $H$. fastigiousus (11-14). Still, no species-specific antivenom has been produced to treat black scorpion envenomations up to now. Despite contradictory opinions regarding scorpion antivenom effectiveness against scorpionism, research on scorpion antivenom production is advancing.

In the present study, species-specific SAV against HFV was produced and its efficacy in the reversal of biochemical changes induced by HFV was determined by challenge method in mice. Species-specific SAV could significantly revert biochemical alterations induced by black scorpion venom. Increase in levels of serum glucose, free amino acid, uric acid, pyruvic acid and total protein as well as decrease in cholesterol after HFV envenomation were notably recovered after SAV treatment. Augmented serum levels of ALP, ACP, LDH and GPT enzyme activity following venom inoculation returned to normal values after treatment with scorpion antivenom. Similar results were reported by several other scientific groups. Freire- 
Maia and Campos (27) suggested the intravenous administration of antivenom as a better manner to neutralize the circulating venom and the venom that is absorbed into the sting site. Kankonkar et al. (9) prepared a potent antiserum against Buthus tamulus scorpion venom capable of neutralizing toxic lethal substances. Reversal of ECG, cardiovascular, hemodynamic, metabolic and hormonal changes in experimental dogs caused by scorpion Mesobuthus tamulus venom were registered after utilization of species-specific antivenom $(10,28,29)$. These previous results on the usefulness of serotherapy against scorpion envenomation support the current study.

According to Ismail (3), scorpion venom presents an overall elimination half-life of 33.7 hours from the body and 26 hours from the peripheral compartments. This long half-life of the venom in the body increases the risk of toxicity and provides an opportunity of treatment with antivenom even few hours after scorpion envenomation. Since scorpions generally inoculate their venom into interstitial space and not directly into circulation, venom must be absorbed and reach circulation to cause toxicity. To reach maximum blood venom concentration approximately 101 minutes are required whereas the venom complete absorption from the sting site takes 7 to 8 hours (3). Based on these data, it may also be concluded that successfulness of serotherapy depends upon specificity, dose, time and route of antivenom administration.

Despite usefulness of serotherapy against scorpionism, a universal anti-scorpion venom has not yet been created to neutralize venoms of different scorpion species. However, in this regard, Devaux et al. (30) produced antibodies against a synthetic polypeptide that represents a conserved region in a set of 25 scorpion toxin sequences. These antibodies have proven to cross-react with several scorpion toxins of different serotypes and to neutralize pharmacological effects and biological activities. However, differences in venom composition and variation in amino acid sequence in active site regions among numerous scorpion species, widely distributed over the globe, limits the possibility of a universal antivenom production. Therefore, it is quite necessary to develop species-specific scorpion antivenoms.

\section{ACKNOWLEGMENTS}

Author is highly thankful to the Head of the Department of Zoology, Deen Dayal Upadhyay Gorakhpur University, for providing laboratory facilities. 


\section{REFERENCES}

1. Amaral CFS, Dias MB, Campolina D, Proietti FA, de Rezende NA. Childrens with adrenergic manifestation of envenomation after Tityus serrulatus scorpion sting are protected from early anaphylactic antivenom reaction. Toxicon. 1994;32(2):211-5.

2. Ghalim N, El-Hafny B, Sebti F, Heikel J, Lezar N, Moustanir R, Benslimane, A. Scorpion venom and serotherpy in Morocco. Am J Trop Med Hyg. 2000;62(2):27783.

3. Ismail M. The scorpion-envenoming syndrome. Toxicon. 1995;33(7):825-58.

4. Gueron M, Ovsyshcher I. What is the treatment for the cardiovascular manifestations of scorpion envenomation? Toxicon. 1987;25(2):121-30.

5. Sofer S, Shahak E, Gueron M. Scorpion envenomation and antivenom therapy. J Pediatr. 1994;124(6):973-8.

6. Abroug F, El Atrous S, Nouira S, Haguiga H, Touzi N, Bouchoucha S. Serotherapy in scorpion envenomation: a randomized controlled trial. Lancet. 1999;354(9182):906-9.

7. De Rezende NA, Dias MB, Campolina D, Chavez-Olortegui C, Diniz C, Amaral CF. Efficacy of antivenom therapy for neutralizing venom antigen in patients stung by Tityus serrulatus scorpion. Am J Trop Med Hyg. 1995;52(3):277-80.

8. Natu VS, Radha Krishna Murthy K, Deodhar, KP. Efficacy of species-specific antiscorpion venom serum (AScVS) against severe, serious scorpion stings (Mesobuthus tamulus concanesis Pocock): an experience from rural hospital in Western Maharastra. J Assoc Physicians India. 2006;54:283-7.

9. Kankonkar RC, Kulakarni DG, Hulikavi CB. Preparation of a potent anti-scorpion venom serum against the venom of red scorpion (Buthus tamulus). J Postgrad Med. 1998;44(4):85-92.

10. Radha Krishna Murthy K, Abbas Zare M, Haghnazari L. The use of serotherapy to reverse ECG and cardiac enzyme changes caused by scorpion Mesobuthus tamulus concanesis, Pocock envenoming. J Venom Anim Toxins. 1999;5(2):154-71.

11. Chaubey MK. Haematological changes after Asian black scorpion Heterometrus fastigiousus Couzijn envenomation. J Adv Zoo. 2008;29:27-31.

12. Chaubey MK, Upadhyay RK. Biochemical and enzymatic changes after black scorpion Heterometrus fastigiousus Couzijn envenomation in experimental albino mice. J Appl Toxicol. 2008; 28(7):874-84. 
13. More SS, Kiran KM, Gadag JR. Dose-dependent serum biochemical alterations in Wistar albino rats after Palamneus gravimanus (Indian black scorpion) envenomation. J Basic Clin Physiol Pharmacol. 2004;15(3-4):263-75.

14. Nirthanan S, Joseph JS, Gopalkrishnakone P, Khoo HE, Cheah LS, Gwee MCE. Biochemical and pharmacological characterization of the venom of the black scorpion Heterometrus spinifer. Biochem Pharmacol. 2002;63(1):49-55.

15. Ouchterlony O. Diffusion-in-gel methods for immunological analysis II. Prog Allergy. 1962;6:30-154.

16. Mendel B, Kemp A, Myers DK. A colorimetric micro-method for determination of glucose. Biochem J. 1954;56(4):639-46.

17. Folin O. Standardized methods for the determination of uric acid in inlaked blood and in urine. J Biol Chem. 1933;101:111-12.

18. Friedeman TE, Haugen GE. Pyruvic acid II. The determination of ketoacids in blood and urine. J Biol Chem. 1943;47:415-42.

19. Spies JR. Colorimetric procedure for amino acids. Methods Enzymol. 1957;3:468-71.

20. Lowry $\mathrm{OH}$, Rosenbrough NJ, Farr AL, Randall RL. Protein measurement with phenol reagent. J Biol Chem. 1951;193(1):265-75.

21. Abell LL, Levy B, Brodie BB, Kendall, FE. A simplified method for the estimation of total cholesterol in serum and demonstration of its specificity. J Biol Chem. 1952;195(1):357-66.

22. Bergmeyer UH. Methods of enzymatic analysis. New York: Academic Press; 1967. 1129 p.

23. Annon TM. Sigma diagnostic: lactate dehydrogenase (quantitative, colorimetric determination in serum, urine and cerebrospinal fluid) at 400-500 nm. Procedure. 1984;500.

24. Reitman A, Frankel SA. Colorimetric method for the determination of serum glutamate-oxaloacetate and serum glutamate-pyruvate transaminase. Am J Clin Pathol. 1957;28:56-8.

25. Armitage P, Berry G, Matthews JNS. Statistical Methods in Medical Research. $4^{\text {th }}$ ed. Oxford: Blackwell Science; 2002: 817 p.

26. Keegan HL. Scorpions of Medical Importance. Mississippi: University Press of Mississippi; 1980, 140 p. 
27. Freire-Maia L, Campos JA. On the treatment of the cardiovascular manifestations of scorpion envenomation. Toxicon. 1987;25(2):125-130.

28. Radha Krishna Murthy K, Abbas Zare M. The use of antivenom reverses hematological and osmotic fragility changes of erythrocytes caused by Indian red scorpion Mesobuthus tamulus concanesis Pocock in experimental envenoming. J Venom Anim Toxins. 2001;7(1):113-38.

29. Radha Krishna Murthy K, Dubey AS, Abbas Zare M, Haghnazari, L. Investigation on the role of insulin and scorpion antivenom in scorpion envenoming syndrome. J Venom Anim Toxins incl Trop Dis. 2003;9(2):202-38.

30. Devaux C, Fourquet P, Granier C. A conserved sequence region of scorpion toxin rendered immunogenic induces broadly cross-reactive, neutralizing antibodies. Eur J Biochem. 1996;242(3):727-35. 